\title{
Community Policing Construction and Development Thinking
}

\author{
Wang Xu \\ Policing Administration Department, Liaoning Police College, Dalian Liaoning, China
}

Keywords: Community policing; Construction; Development; Police protection; rational thinking

\begin{abstract}
Community policing from the sixties and seventies of the 20th century western the fourth policing revolution, its core idea is the police based on community, geared to the needs of the masses, through close relationship between the people, to strengthen cooperation between the people, to find and solve the problem of community policing. This paper on the basis of the theory of community policing, combined with the actual situation of our country in recent years, the implementation of community policing strategy, organizational behavior, public management, public policy analysis, public economics and human resource management of public management theory as the instruction, to the current situation of the implementation of community policing construction of our country has carried on the comprehensive analysis, especially on the problems existing in the implementation of the construction of police emphasis; On the basis of the analysis, the inductive method, from the organization management, operating mechanism, "community" and the "auxiliary police", to prevent and control crime, police protection and so on six aspects, summary the problems generally exists in the present stage community policing, form of expression; The paper analyzes and points out the causes or constraints of the formation of the problems. Then, on this basis, on how to solve the above problems of community policing has carried on the rational thinking, concrete from six aspects puts forward the basic thinking and countermeasure to solve the problem of it.
\end{abstract}

\section{Introduction}

Community policing is a hot issue that many national police are concerned about, and it is also the development trend of police reform in the world today. In recent years, our country in the process of the implementation of community policing, has obtained certain achievements, but there are also some problems, therefore, further discusses the problems existing in the construction of community policing in China at the present stage, it has important theoretical value and practical significance. Community policing as a new kind of policing strategies, for thinking and way of policing is the core of the contemporary western policing revolution, began in the 1960 s, early 70 generations, successively in Britain, the United States, Australia, Japan and other countries began to implement, so s introduced into our country.

Due to the historical background, basic national conditions and the police practice there are some differences, therefore the domestic and foreign scholars on "community service for the understanding of the meaning of", namely on the definition of "community policing" (explain) are also different. That people generally think of: the concept of community policing is a collection type, is a kind of reputation service theory, is also the specific policing work, can also from the deeper understanding as it is a "fundamental supplemented, cure table" crime prevention strategies. Its basic connotation is: based on the community will be the main focus of the police's attention and time to expand community services, cooperation of the police and the people, and further the form of service, close relationship between the people and obtain public support, strengthen the consciousness of public participation and seek solution to affect the normal life community concerns, to start the enemy, in order to achieve "quite little, good order, social stability and public satisfaction" as the fundamental goal of a kind of policing idea and strategy of police. At the same time, with the further deepening of the reform of the housing system, it is an inevitable trend of social management to live mainly in the community, to manage the community and to become the social people. To be "an" is the greatest 
wish of the people. Therefore, it is a new task facing the public security work in the current community.

\section{Community policing satisfaction survey}

Descriptive statistics of the overall satisfaction of the residents in the police work. According to the statistical results of the residents' overall satisfaction with the police work (table 1), the total satisfaction of the police work among the 300 residents was 165 , accounting for $55 \%$ of the total. The basic satisfaction of 84 people, accounting for $28 \%$ of the total; Unsatisfied 51 people, accounting for 17 percent of the total. Based on the "basic satisfaction", the overall satisfaction rate of the police work was $83 \%$

Table 1 describes statistical tables of the residents' overall satisfaction with the police work

\begin{tabular}{ccccc}
\hline & Frequency & Percent & Valid Percent & Cumulative Percent \\
\hline Satisfied & 165 & 55 & 55 & 55 \\
Basic satisfaction & 84 & 28 & 28 & 83 \\
Not satisfied & 51 & 17 & 17 & 100 \\
total & 300 & 100 & 100 & \\
\hline
\end{tabular}

From the residents' satisfaction of residence social security situation described as seen in the results (table 2), in the 300 people surveyed, satisfied with the residence social security conditions of 220 people, $73.3 \%$ of the total; The basic satisfaction of 53 people, accounting for $17.7 \%$ of the total; Unsatisfied 27, accounting for 9\% of the total. Based on "basic satisfaction", the satisfaction rate of residents' social security situation was $91 \%$.

Table 2 describes the social security satisfaction of the residents

\begin{tabular}{ccccc}
\hline & Frequency & Percent & Valid Percent & Cumulative Percent \\
\hline Satisfied & 220 & 73.3 & 73.3 & 73.3 \\
Basic satisfaction & 53 & 17.7 & 17.7 & 91 \\
Not satisfied & 27 & 9 & 9 & 100 \\
total & 300 & 100 & 100 & \\
\hline
\end{tabular}

From residents of the public security organ law enforcement situation satisfaction describe as seen in the results (table 3), in the 300 people surveyed, satisfied with the public security organ law enforcement situation of 165 people, accounting for 55\% of the total number of: basic satisfied with 84 people, $28 \%$ of the total; Unsatisfied 51 people, accounting for 17 percent of the total. Based on "basic satisfaction", the satisfaction rate of residents to the law enforcement of public security organs was $83 \%$.

Table 3 the residents' satisfaction with the law enforcement of public security organs

\begin{tabular}{ccccc}
\hline & Frequency & Percent & Valid Percent & Cumulative Percent \\
\hline Satisfied & 165 & 55 & 55 & 55 \\
Basic satisfaction & 84 & 28 & 28 & 83 \\
Not satisfied & 51 & 17 & 17 & 100 \\
total & 300 & 100 & 100 & \\
\hline
\end{tabular}

According to the statistics of the residents' efficiency in the performance of the public security organs (table 4), 188 people were satisfied with the efficiency of the public security organs in the 300 residents surveyed, accounting for $62.7 \%$ of the total. The basic satisfaction of 61 persons, accounting for $20.3 \%$ of the total; Unsatisfied 51 people, accounting for 17 percent of the total. Based on "basic satisfaction", the satisfaction rate of residents' efficiency in the public security organs was $83 \%$. 
Table 4 residents' statistical table of efficiency satisfaction

\begin{tabular}{ccccc}
\hline & Frequency & Percent & Valid Percent & Cumulative Percent \\
\hline Satisfied & 188 & 62.7 & 62.7 & 62.7 \\
Basic satisfaction & 61 & 28 & 28 & 83 \\
Not satisfied & 51 & 17 & 17 & 100 \\
total & 300 & 100 & 100 & \\
\hline
\end{tabular}

According to the statistics of the residents' attitude to the service attitude of the public security organs (table 5), they found that among the 300 surveyed residents, 60 were satisfied with the service attitude of the public security organs, which accounted for $53.3 \%$ of the total. The basic satisfaction of 62 people, accounting for $20.7 \%$ of the total; Unsatisfied 78 people, accounting for $26 \%$ of the total. Based on "basic satisfaction", the satisfaction rate of residents' attitude to the service of public security organs was $74 \%$

Table 5 description of public security service attitude satisfaction

\begin{tabular}{ccccc}
\hline & Frequency & Percent & Valid Percent & Cumulative Percent \\
\hline Satisfied & 160 & 53.3 & 53.3 & 53.3 \\
Basic satisfaction & 62 & 20.7 & 20.7 & 74 \\
Not satisfied & 78 & 26 & 26 & 100 \\
total & 300 & 100 & 100 & \\
\hline
\end{tabular}

According to the statistics of residents' description of the public security organ's integrity, the report shows that among the 300 residents surveyed, 176 were satisfied with the integrity of the public security organs, accounting for $58.7 \%$ of the total. The basic satisfaction of 64 persons, accounting for $21.3 \%$ of the total; an unhappy 60 , or $20 \%$ of the total. Based on the "basic satisfaction", the satisfaction rate of residents to the public security organs was $80 \%$

Table 6 residents' satisfaction survey of public security organs

\begin{tabular}{ccccc}
\hline & Frequency & Percent & Valid Percent & Cumulative Percent \\
\hline Satisfied & 176 & 58.7 & 58.7 & 58.7 \\
Basic satisfaction & 64 & 21.3 & 21.3 & 80 \\
Not satisfied & 60 & 20 & 20 & 100 \\
total & 300 & 100 & 100 & \\
\hline
\end{tabular}

The residents' satisfaction with the police work was summarized. Overall satisfaction with police work was $83 \%$ for community residents. On the condition of community policing satisfaction was $91 \%$, the law enforcement activities of satisfaction was $83 \%$, the efficiency of satisfaction was $83 \%$, the cultivation of the degree of satisfaction was $80 \%$, the service attitude of satisfaction was $74 \%$. Those residents of policing work satisfaction are higher, and several aspects of policing work order of satisfaction from high to low were: community policing in a law enforcement activities, efficiency, and integrity situation service attitude. It can be explained that the community security situation is good, the law enforcement activities of the public security organs are more standardized and the efficiency is higher, but the integrity of the government is still available, and the service attitude needs to be improved.

\section{Community policing development thinking}

Establish full-time community police work mechanism, namely clear not to take part in community police patrol police on duty, not to participate in our zone, not directly hit the investigation constants, specializing in community work and mass work. One is to ensure that community policing is in place. The regulations on the adjustment and approval of police posts in the community should be issued to regulate the adjustment and approval process of the civil police in the community. The second is to clarify the responsibilities of the community. We will further 
standardize the daily work contents, constants and standards of the police, basic information collection, population management and safety precautions. Set up a global unified community basic information collection platform account, and set up the account of the establishment of human resources. The third is improve the supervision mechanism of community policing. In internal radio call and video inspection, field supervision, monitoring platform, police room on monitoring way, in the external expanding scope of community police and community policing room police information bulletin, accepts the populace to supervise, increase the intensity of work.

On the basis of existing work, continue to deepen the party and government leaders, public security, department coordination, social participation pattern of work, the party committees and governments to support to the greatest extent, play a role of socialization and mercerization, and the construction of community policing again into a new step. First, establish a coordinating mechanism for the work. The county bureau and the police station should report to the party committee on a regular basis and put forward work Suggestions. The party committee of the district and county towns and villages should increase the policy inclination and support to form the synergy of the promotion work. The second is to the anti-social security mechanism. Insist on department unified leadership, to have a certain qualification support commercial insurance company, community volunteers peace should be brought into the scope of commercial insurance, excitation force to prevent enthusiasm, improve case prevention and control

Property units, as the contractual and operational units responsible for the management and service of communities, are responsible for the prevention of public security. To do this, select pilot implementation of community property units to the district public security responsibility sharing model, further defined property units within the existing legal framework of security guard responsibility, and coordinate living building link establishment and public security departments to prevent responsibility reporting on a regular basis and rating mechanism, and develop property units such as the role of social organizations in the construction of community policing.

\section{Summary}

This paper on the basis of the theory of community for service, combined with our country in recent years, the actual situation of the community is business strategy, organizational behavior, public management, public policy analysis, public economics and human resource management of public management theory as the instruction, to our country current situation of the construction of the implementation of community policing, and has carried on the comprehensive analysis, especially for the construction of service "focuses on the problems existing in the analysis; On the basis of the analysis, the inductive method, from the organization management, operating mechanism, "community" and "bitter" auxiliary work, crime prevention and control, with security and so on six aspects, summary the problems generally exists in the present stage community policing, form of expression; The paper analyzes and points out the causes or constraints of the formation of the problems. Then, on this basis, on how to solve the above problems of community policing has carried on the rational thinking, concrete from six aspects puts forward the basic thinking and countermeasure to solve the problem of it.

\section{References}

[1] Goldstein, H. "Improving Policing:A Problem-Oriented Approach", in Oliver, W. M. Community Policing Classical Readings [M]. Prentice Hall, 2000: 22-23

[2] Kelling,G L.\&Moore, M. H. "The Evolving Strategy of Policing", in Oliver, W. M. Community Policing Classical Readings [M]. Prentice Hall, 2000: 98-99,103

[3] Moore, M. H.\&Trojanowicz, R. C. "Policing and the Fear of Crime", in 4liver,W. M. Community Policing Classical Readings [M]. PrenticeHall, 2000: 84,86,12

[4] Peak, K. J.\&Glensor, R. W. Community Policing and Problem Solving Strategies and Practices (3 
rd edition) [M]. Prentice Hall, 2002: 83.

[5] Zhang yilin. The development trend of community in the market economy system [J]. Jiangxi Public Security Journal, 2004, 6: 91-93. (In Chinese).

[6] Fornell, C.\&Johnson, M. D. The American Customer Satisfaction Index [J]. Narhwe, Purpose and Findings. Journal of Marketing, 2016(60):7-18. 